\title{
Refrigeration Storage Effect on Nutritive Value and Antioxidant Properties of Five Leafy Vegetables Consumed in Northern Côte d'Ivoire (Ivory Coast)
}

\author{
Patricia D. Oulai, Lessoy T. Zoué", Sébastien L. Niamké \\ Biotechnology Laboratory, Biosciences Faculty, Félix Houphouet-Boigny University, Abidjan 22, Ivory Coast
}

\author{
Email address: \\ y.lessoy@yahoo.fr (L.T. Zoué)
}

\section{To cite this article:}

Patricia D. Oulai, Lessoy T. Zoué, Sébastien L. Niamké. Refrigeration Storage Effect on Nutritive Value and Antioxidant Properties of Five Leafy Vegetables Consumed in Northern Côte d'Ivoire (Ivory Coast). Journal of Food and Nutrition Sciences. Vol. 3, No. 1, 2015, pp. $24-31$. doi: $10.11648 /$ j.jfns.20150301.14

\begin{abstract}
Storage and processing technologies have been utilized for centuries to prevent post harvest losses of vegetables and to transform them into safe, delicious and stable products. The aim of this study was to evaluate the effect of refrigeration storage $\left(4^{\circ} \mathrm{C}\right)$ on the nutritional value of five leafy vegetables (Hibiscus sabdariffa, Amaranthus hybridus, Andasonia digitata, Vigna unguiculata and Ceiba patendra) that are consumed in Northern Côte d'Ivoire. The selected samples were subjected to storage at $4{ }^{\circ} \mathrm{C}$ for 5,10 and 15 days and the physicochemical properties were determined using standard methods. Fresh selected samples were used as the control. The result of the study revealed that increased storage time affected the nutritional value of the selected leafy vegetables. The registered losses at 15 days of refrigeration storage were as follow: ash (2.419.70\%), proteins (5.66- 18.97\%), vitamin C (11.43- 41.29\%), carotenoids (25.44- 41.29\%), oxalates (12.43- 14.55\%), phytates (35.03- $44.10 \%)$. It was observed an increase (0.17- $2.41 \%)$ in total phenolic content during storage. In addition, a small increase $(0.88-2.66 \%)$ of fibres content was also observed in the studied leafy vegetables stored under refrigeration at $4{ }^{\circ} \mathrm{C}$. Furthermore, after 15 days of storage at $4^{\circ} \mathrm{C}$ the residual contents of minerals were: calcium $(308.30-858.75 \mathrm{mg} / 100 \mathrm{~g})$. Magnesium (213.64- 610.14 mg/100g), potassium (565.32-1844.08 mg/100g), iron (49.29- $160.53 \mathrm{mg} / 100 \mathrm{~g})$ and zinc (17.95$34.06 \mathrm{mg} / 100 \mathrm{~g})$. The result of the present study suggests that vegetables should be stored in cold storage for a short time (less to five days) in order to avoid loss of essential nutrients.
\end{abstract}

Keywords: Leafy Vegetables, Nutritive Value, Refrigeration Storage, Antioxidant Properties

\section{Introduction}

Green leafy vegetables hold an important place in well-balanced diets. Vegetables include leaves, stems, roots, flowers, seed, fruits, bulbs, tubers and fungi $[1,2]$ than can be eaten. These plants have been reported to be particularly rich in precursor of vitamin A and iron, two nutrients that are currently believed to be deficient in the diet of people in many countries [3]. The vegetables are also rich sources of vitamin $\mathrm{C}$, proteins, fibres and minerals (potassium, phosphorous, calcium and zinc) [4]. In addition to antioxidant and vitamins, vegetables also contain high contents of phytochemical such as phenolic compounds including flavonoids, which have been implicated in the prevention of aging related diseases such as cancer, arteriosclerosis and diabete. African leafy vegetables play a significant role in food security of the underprivileged in both urban and rural setting and are also vital for the income generation [5]. Among the twenty hundred and seven (207) leafy vegetables widely consumed in tropical Africa, about twenty (20) species of leafy vegetables belonging to 6 botanical families, are widely consumed and cultivated by Ivorian population [6]. Furthermore, the consumption of these leafy vegetables is linked to the region and ethno-botanical studies have stated that most people in Northern Côte d'Ivoire consume indigenous green leafy vegetables such as Amaranthus hybridus "boronbrou", Andasonia digitata "baobab", Ceiba patendra "fromager", Hibiscus sabdariffa "dah" and Vigna unguiculata "haricot" [7,8]. Many fresh leafy vegetables have a shelf life of only few days before they are unsafe or undesirable for consumption. In fact, Vegetables are highly perishable foods subject to rapid deterioration by microorganisms, enzymes, or oxidation reactions. Storage and processing technologies have been utilized for centuries to transform these perishable vegetables into safe, delicious and 
stable products [9]. Refrigeration slows down the chemical and biological processes in food and the accompanying deterioration and the loss of quality. Also, refrigeration down the respiration of fruits and vegetables and allows for longer shelf lives [10]. Owing to substantial loss of unused fresh produce, use of postharvest preservation methods such as refrigeration and freezing might extend their shelf life but may also affect the nutritional content of these crops [11]. A literature review [10] also concluded that very few studies have monitored changes in nutritional parameters in leafy vegetables commodity from harvest through storage and domestic cooking. The aim of this study was to evaluate the impact of refrigeration storage at $4{ }^{\circ} \mathrm{C}$ on the nutritive value of selected fresh green leafy vegetables.

\section{Material and Methods}

\subsection{Samples Collection}

Leafy vegetables (Amaranthus hybridus, Andasonia digitata, Ceiba patendra, Hibiscus sabdariffa and Vigna unguiculata) were collected fresh and at maturity from cultivated farmlands located at Dabou (latitude: $5^{\circ} 19^{\prime}$ 14 " North; longitude: $4^{\circ} 22^{\prime} 59^{\prime \prime}$ West) (Abidjan District). The samples were harvested at the early stage (between one and two weeks of the appearance of the leaves). These plants were previously authenticated by the National Floristic Center (University Felix Houphouët-Boigny, Abidjan-Côte d'Ivoire). After harvesting, the fresh leafy vegetables were immediately transported in icebox $\left(4^{\circ} \mathrm{C}\right)$ to the laboratory for further treatment.

\subsection{Samples Processing}

The fresh leafy vegetables were destalked, washed with deionized water and edible portions were separated from the inedible portion. The edible portions were chopped into small pieces $(500 \mathrm{~g})$ and allowed to drain at ambient temperature. Each sample was divided into two lots. The first lot (raw, 250g) used as control was dried in an oven (Memmert, Germany) at $60^{\circ} \mathrm{C}$ for $72 \mathrm{~h} \mathrm{[12].} \mathrm{The} \mathrm{dried} \mathrm{leaves} \mathrm{were} \mathrm{ground} \mathrm{with} \mathrm{a}$ laboratory crusher (Culatti, France) and were immediately analyzed. The second lot $(250 \mathrm{~g})$ was stored in polyethylene bags and then placed at refrigerator $\left(4^{\circ} \mathrm{C}\right)$ for 5,10 and 15 days. After refrigeration storage times, the samples were dried and treated as the control.

\subsection{Chemicals}

All solvents (n-hexane, petroleum ether, acetone, ethanol and methanol) were purchased from Merck. Standards used (gallic acid, $\beta$-carotene) and reagents (metaphosphoric acid, Folin-Ciocalteu, DPPH) were purchased from Sigma-Aldrich. All chemicals used in the study were of analytical grade.

\subsection{Nutritive Properties}

\subsubsection{Proximate Analysis}

Ash, proteins and lipids were determined using official methods [12]. For crude fibres, $2 \mathrm{~g}$ of dried powdered sample were digested with $0.25 \mathrm{M}$ sulphuric acid and $0.3 \mathrm{M}$ sodium hydroxide solution. The insoluble residue obtained was washed with hot water and dried in an oven (Memmert, Germany) at $100{ }^{\circ} \mathrm{C}$ until constant weight. The dried residue was then incinerated, and weighed for the determination of crude fibres content. Carbohydrates and calorific value were calculated using the following formulas [13]:

Carbohydrates (dry matter basis):

$$
100-(\% \text { proteins }+\% \text { lipids }+\% \text { ash }+\% \text { fibres })
$$

Calorific value (dry matter basis):

$$
\begin{gathered}
(\% \text { proteins } \times 2.44)+(\% \text { carbohydrates } \times 3.57) \\
+(\% \text { lipids } \times 8.37)
\end{gathered}
$$

The results of ash, fibres, proteins, lipids and carbohydrates contents were expressed on dry matter basis.

\subsubsection{Anti-Nutritional Factors Determination}

Oxalates content was performed using by titration method [14]. One (1) g of dried powdered sample was weighed into $100 \mathrm{~mL}$ conical flask. A quantity of $75 \mathrm{~mL}$ of sulphuric acid (3 $\mathrm{M})$ was added and stirred for $1 \mathrm{~h}$ with a magnetic stirrer. The mixture was filtered and $25 \mathrm{~mL}$ of the filtrate was titrated while hot against $\mathrm{KMnO} 4$ solution $(0.05 \mathrm{M})$ to the end point.

Phytates contents were determined using the Wade's reagent colorimetric method [15]. A quantity (1 g) of dried powdered sample was mixed with $20 \mathrm{~mL}$ of hydrochloric acid $(0.65 \mathrm{~N})$ and stirred for $12 \mathrm{~h}$ with a magnetic. The mixture was centrifuged at $12000 \mathrm{rpm}$ for $40 \mathrm{~min}$. An aliquot $(0.5 \mathrm{~mL})$ of supernatant was added with $3 \mathrm{~mL}$ of Wade's reagent. The reaction mixture was incubated for $15 \mathrm{~min}$ and absorbance was measured at $490 \mathrm{~nm}$ by using a spectrophotometer (PG Instruments, England). Phytates content was estimated using a calibration curve of sodium phytate $(10 \mathrm{mg} / \mathrm{mL})$ as standard.

\subsubsection{Mineral Analysis}

Minerals contents were determined by the ICP-MS (inductively coupled argon plasma mass spectrometer) method [16].The dried powdered samples ( $5 \mathrm{~g}$ ) were burned to ashes in a muffle furnace (Pyrolabo, France). The ashes obtained were dissolved in $10 \mathrm{~mL}$ of $\mathrm{HCl} / \mathrm{HNO}_{3}$ and transferred into $100 \mathrm{~mL}$ flasks and the volume was made up using deionized water. The mineral composition of each sample was determined using an Agilent 7500c argon plasma mass spectrometer. Calibrations were performed using external standards prepared from a 1000 ppm single stock solution made up with $2 \%$ nitric acid.

\subsubsection{Antioxidant Properties}

\section{(i). Vitamin C and Carotenoids Determination}

Vitamin $\mathrm{C}$ contained in analyzed samples was determined by titration [17]. About $10 \mathrm{~g}$ of ground fresh leaves were soaked for $10 \mathrm{~min}$ in $40 \mathrm{~mL}$ metaphosphoric acid-acetic acid $(2 \%, \mathrm{w} / \mathrm{v})$. The mixture was centrifuged at $3000 \mathrm{rpm}$ for 20 min and the supernatant obtained was diluted and adjusted 
with $50 \mathrm{~mL}$ of bi-distilled water. Ten (10) $\mathrm{mL}$ of this mixture was titrated to the end point with dichlorophenol-indophenol (DCPIP) $0.5 \mathrm{~g} / \mathrm{L}$.

Carotenoids were extracted and quantified by using a spectrophotometric method [18]. Two (2) g of ground fresh leaves were mixed three times with $50 \mathrm{~mL}$ of acetone until loss of pigmentation. The mixture obtained was filtered and total carotenoids were extracted with $100 \mathrm{~mL}$ of petroleum ether. Absorbance of extracted fraction was then read at $450 \mathrm{~nm}$ by using a spectrophotometer (PG Instruments, England). Total carotenoids content was subsequently estimated using a calibration curve of $\beta$-carotene $(1 \mathrm{mg} / \mathrm{mL})$ as standard.

\section{(ii). Polyphenols Determination}

Polyphenols were extracted and determined using Folin-Ciocalteu's reagent [19]. A quantity (1 g) of dried powdered sample was soaked in $10 \mathrm{~mL}$ of methanol $70 \%(\mathrm{v} / \mathrm{v})$ and centrifuged at $1000 \mathrm{rpm}$ for $10 \mathrm{~min}$. An aliquot $(1 \mathrm{~mL})$ of supernatant was oxidized with $1 \mathrm{~mL}$ of Folin-Ciocalteu's reagent and neutralized by $1 \mathrm{~mL}$ of $20 \%$ (w/v) sodium carbonate. The reaction mixture was incubated for $30 \mathrm{~min}$ at ambient temperature and absorbance was measured at $745 \mathrm{~nm}$ by using a spectrophotometer (PG Instruments, England). The polyphenols content was obtained using a calibration curve of gallic acid $(1 \mathrm{mg} / \mathrm{mL})$ as standard.

\section{(iii). Antioxidant Activity}

Antioxidant activity assay was carried out using the 2,2-diphenyl-1-pycrilhydrazyl (DPPH) spectrophotometric method [20]. About $1 \mathrm{~mL}$ of $0.3 \mathrm{mM}$ DPPH solution in ethanol was added to $2.5 \mathrm{~mL}$ of sample solution (1 $\mathrm{g}$ of dried powdered sample mixed in $10 \mathrm{~mL}$ of methanol and filtered through Whatman No. 4 filter paper) and was allowed to react for $30 \mathrm{~min}$ at room temperature. Absorbance values were measured with a spectrophotometer (PG Instruments, England) set at $415 \mathrm{~nm}$. The average absorbance values were converted to percentage antioxidant activity using the following formula:

Antioxidant activity $(\%)=100-[($ Abs of sample - Abs of blank) x 100/Abs positive control]

\subsubsection{Statistical Analysis}

In the experiment, each test for the samples was analyzed in triplicate. The data were expressed as means \pm standard deviation (SD). Differences between means were analyzed by analysis of variance (one way ANOVA) coupled with Duncan's test using STATISTICA 7.1 (StatSoft) software. Statistical significance was measured at $\mathrm{p}<0.05$.

\section{Results and Discussion}

\subsection{Proximate composition}

The proximate composition of leafy vegetables stored at $4^{\circ} \mathrm{C}$ is presented in Table 1 . During refrigeration storage at $4{ }^{\circ} \mathrm{C}$, small fluctuation $(\mathrm{p}>0.05)$ in moisture, ash, fibres, proteins, lipids, carbohydrates contents were observed compared to freshly samples. The slight decrease in moisture contents $(70.45-86.05 \%$ to $66.62-84.18 \%)$ during refrigeration storage was due to the respiration and others senescence-related metabolic processes [10]. The stable values obtained may be due to refrigeration temperature $\left(4^{\circ} \mathrm{C}\right)$ which slows down the respiration and transpiration rates. The ash content after 5 days of refrigeration ranged from $8.51 \pm$ $0.33 \%$ (A. hybridus) to $24.81 \pm 0.42 \%$ (C. patendra). These values were closed to $7.89 \pm 0.47 \%$ and $23.18 \pm 0.04 \%$ after 15 days of refrigeration. The reduced ash contents could be attributed to the loss water carrying off the minerals during transpiration stage [10]. Besides the decrease rate from (0.26-3.35\%) to (2.41-10.75\%) at 5 and 15 days of storage respectively, the studied leafy vegetables may be considered as a good source of minerals when compared to values $(2-$ $10 \%)$ obtained for cereals and tubers [21]. Storage in refrigerator at $4{ }^{\circ} \mathrm{C}$ of the selected leafy vegetables resulted in slight increase $(0.09-0.61 \%)$ to $(0.88-2.66 \%)$ in their crude fibres contents $(p>0.05)$ after 5 and 15 days of storage, respectively. The increase in total fibres may be due to textural changes such as wilting and shriveling observed during refrigeration of vegetables [22]. Indeed, the high level of crude fibres in these leafy vegetables would be advantageous for their active role in the regulation of intestinal transit, increasing dietary bulk due to their ability to absorb water [23]. As concern protein contents, storage at $4^{\circ} \mathrm{C}$ caused 0.13 to $5.98 \%$ reduction after 5 days. It's worth noting that plant foods which provide more than $12 \%$ of their calorific value from proteins have been shown to be good source of proteins [24]. This suggests that all the leafy vegetables investigated may be good sources of proteins and could play a significant role in providing cheap and available proteins for rural communities. The relatively low values of lipids contents after 5 days of refrigeration, corroborates the findings of many authors which showed that leafy vegetables are poor sources of fat [25]. However, it's important to note that diet providing $1-2 \%$ of its caloric energy as fat is said to be sufficient to human beings, as excess fat consumption yields to cardiovascular disorders such as atherosclerosis, cancer and aging [26]. Therefore, the consumption of these leafy vegetables in large amount may be recommended to individuals suffering from obesity. The estimated caloric values agree with general observation that vegetables have low energy values due to their low crude fat and relatively high level of moisture [27].

\subsection{Mineral Composition}

Mineral content is an essential component of the nutritive value of fresh green leafy vegetable. Table 2 showed the mineral composition of leafy vegetables stored in refrigerator at $4{ }^{\circ} \mathrm{C}$. The residual contents of minerals showed statistical difference $(\mathrm{p}<0.05)$ after 5 days of storage at $4{ }^{\circ} \mathrm{C}$. These contents were: calcium (396.70-920.90 $\mathrm{mg} / 100 \mathrm{~g})$, magnesium (228.19-661.01 $\mathrm{mg} / 100 \mathrm{~g}), \quad$ potassium (702.32-1967.63 mg/100g), iron (57.66-168.09 mg/100g) and zinc (21.81-39.74 mg/100g). These observed reductions may be due to the small losses of ashes by transpiration phenomena during refrigeration. There was a significant 
difference $(p<0.05)$ in mineral contents between the refrigerated leafy vegetables and this variability was expected since the green leafy vegetables belonged to different botanic families. Considering the recommended dietary allowance (RDA) for minerals [28], consumption of 5 -days refrigerated leafy vegetables could cover at least $50 \%$ RDA. Therefore, they could contribute substantially for improving human diet. Calcium and phosphorus are associated for growth and maintenance of bones, teeth and muscles [29]. As concern magnesium, this mineral is known to prevent cardiomyopathy, muscle degeneration, growth retardation, congenital malformations and bleeding disorders [30]. Iron is important in the diet of pregnant, infants and the elderly to reduce cases of deficiency associated with disease such as anemia [31]. Zinc is important for vitamin A and vitamin E metabolism [28, 32]. To predict the bioavailability of calcium and iron, anti-nutrients to nutrients ratios of were calculated (Table 3 ). It was observed a small decrease of anti-nutritional factors (oxalates and phytates) in the refrigerated samples compared to the fresh green leafy vegetables (Figure 1). The calculated [oxalates]/[Ca] and [phytates]/[Ca] ratios in all the species, excepted $H$. sabdariffa, were below the critical level of 2.5 known to impair calcium bioavailability [33]. It was also observed that the calculated [phytates] $/[\mathrm{Fe}]$ ratios of $H$. sabdariffa were above the critical level of 0.4 . This implies that the phytates of these leafy vegetables may hinder iron bioavailability [34]. However, the [phytates]/[Fe] ratios could be considerably reduced after processing such as soaking, boiling or frying [35].

Table 1. Proximate composition of refrigerated $\left(4^{\circ} \mathrm{C}\right)$ leafy vegetables consumed in Northern Côte d'Ivoire

\begin{tabular}{|c|c|c|c|c|c|c|c|}
\hline & Moisture (\%) & $\operatorname{Ash}^{*}(\%)$ & Fibres* (\%) & Proteins* (\%) & Lipids* (\%) & Carbohydrates* (\%) & $\begin{array}{c}\text { Energy* (kcal } \\
/ 100 \mathrm{~g}) \\
\end{array}$ \\
\hline \multicolumn{8}{|c|}{ H. sabdariffa } \\
\hline 0 days & $86.05 \pm 1.35 \mathrm{a}$ & $10.30 \pm 0.10 \mathrm{a}$ & $14.27 \pm 1.70 \mathrm{a}$ & $14.47 \pm 0.10 \mathrm{a}$ & $4.75 \pm 0.15 a$ & $56.21 \pm 1.78 \mathrm{a}$ & $275.71 \pm 0.55 \mathrm{a}$ \\
\hline 5 days & $85.73 \pm 0.53 a$ & $10.13 \pm 0.02 \mathrm{a}$ & $14.30 \pm 0.35 \mathrm{a}$ & $14.01 \pm 0.03 b$ & $4.61 \pm 0.01 \mathrm{a}$ & $56.95 \pm 0.41 \mathrm{a}$ & $276.09 \pm 1.28 \mathrm{a}$ \\
\hline 10 days & $84.43 \pm 0.46 a$ & $9.97 \pm 0.38 \mathrm{a}$ & $14.50 \pm 1.41 \mathrm{a}$ & $13.78 \pm 0.06 b$ & $4.44 \pm 0.03 b$ & $57.31 \pm 0.95 \mathrm{a}$ & $275.39 \pm 3.77 \mathrm{a}$ \\
\hline 15 days & $84.18 \pm 0.22 \mathrm{a}$ & $9.31 \pm 0.27 b$ & $14.65 \pm 1.96 \mathrm{a}$ & $13.15 \pm 0.08 \mathrm{~b}$ & $3.75 \pm 0.05 \mathrm{c}$ & $60.13 \pm 3.83 a$ & $275.75 \pm 3.03 \mathrm{a}$ \\
\hline \multicolumn{8}{|c|}{ A. hybridus } \\
\hline 0 days & $72.98 \pm 0.10 \mathrm{a}$ & $8.59 \pm 1.34 \mathrm{a}$ & $17.80 \pm 0.30 \mathrm{a}$ & $13.25 \pm 0.13 \mathrm{a}$ & $2.15 \pm 0.01 \mathrm{a}$ & $58.21 \pm 1.78 \mathrm{a}$ & $305.19 \pm 7.73 \mathrm{a}$ \\
\hline 5 days & $72.28 \pm 0.05 a$ & $8.51 \pm 0.33 a$ & $17.05 \pm 2.47 \mathrm{a}$ & $13.12 \pm 0.10 \mathrm{a}$ & $1.93 \pm 0.03 \mathrm{a}$ & $59.39 \pm 2.10 \mathrm{a}$ & $260.20 \pm 7.77 b$ \\
\hline 10 days & $71.81 \pm 0.58 \mathrm{a}$ & $8.15 \pm 1.43 \mathrm{a}$ & $17.20 \pm 0.35 \mathrm{a}$ & $12.91 \pm 0.04 \mathrm{a}$ & $1.53 \pm 0.04 \mathrm{~b}$ & $60.21 \pm 1.70 \mathrm{a}$ & $259.27 \pm 6.54 \mathrm{~b}$ \\
\hline 15 days & $70.57 \pm 0.10 \mathrm{a}$ & $7.89 \pm 0.47 \mathrm{a}$ & $17.34 \pm 1.41 \mathrm{a}$ & $12.50 \pm 0.01 \mathrm{~b}$ & $1.00 \pm 0.06 \mathrm{c}$ & $61.11 \pm 1.84 \mathrm{a}$ & $257.04 \pm 7.00 \mathrm{~b}$ \\
\hline \multicolumn{8}{|c|}{ A. digitata } \\
\hline 0 days & $77.63 \pm 0.15 \mathrm{a}$ & $10.97 \pm 0.4 \mathrm{a}$ & $12.56 \pm 0.45 \mathrm{a}$ & $18.08 \pm 0.10 \mathrm{a}$ & $2.18 \pm 0.03 \mathrm{a}$ & $56.23 \pm 1.25 \mathrm{c}$ & $267.03 \pm 4.00 \mathrm{~b}$ \\
\hline 5 days & $77.28 \pm 0.05 \mathrm{a}$ & $10.87 \pm 0.05 \mathrm{a}$ & $12.60 \pm 1.36 \mathrm{a}$ & $17.65 \pm 0.14 b$ & $1.71 \pm 1.01 \mathrm{~b}$ & $57.75 \pm 1.57 \mathrm{c}$ & $263.56 \pm 3.00 \mathrm{~b}$ \\
\hline 10 days & $76.78 \pm 0.40 \mathrm{a}$ & $10.23 \pm 0.10 \mathrm{~b}$ & $12.78 \pm 0.35 \mathrm{a}$ & $16.91 \pm 0.01 \mathrm{c}$ & $1.22 \pm 1.03 \mathrm{c}$ & $60.84 \pm 0.21 b$ & $289.59 \pm 1.03 \mathrm{a}$ \\
\hline 15 days & $76.18 \pm 0.04 a$ & $9.79 \pm 0.20 \mathrm{~b}$ & $12.80 \pm 1.83 \mathrm{a}$ & $14.65 \pm 0.04 \mathrm{~d}$ & $0.58 \pm 1.04 \mathrm{~d}$ & $64.23 \pm 2.55 \mathrm{a}$ & $269.89 \pm 9.55 b$ \\
\hline \multicolumn{8}{|c|}{ V. unguiculata } \\
\hline 0 days & $80.04 \pm 0.56 a$ & $11.17 \pm 0.25 \mathrm{a}$ & $18.00 \pm 0.92 \mathrm{a}$ & $21.96 \pm 0.30 \mathrm{a}$ & $4.23 \pm 0.25 \mathrm{a}$ & $44.64 \pm 1.72 b$ & $248.35 \pm 1.33 b$ \\
\hline 5 days & $79.80 \pm 0.14 \mathrm{a}$ & $11.14 \pm 0.16 \mathrm{a}$ & $18.11 \pm 1.95 \mathrm{a}$ & $21.93 \pm 0.04 \mathrm{a}$ & $3.92 \pm 0.03 \mathrm{~b}$ & $44.90 \pm 4.71 b$ & $246.62 \pm 1.17 \mathrm{~b}$ \\
\hline 10 days & $78.92 \pm 0.39 a$ & $11.07 \pm 0.93 \mathrm{a}$ & $18.25 \pm 2.47 \mathrm{a}$ & $20.88 \pm 0.07 b$ & $3.20 \pm 0.04 \mathrm{c}$ & $46.60 \pm 3.52 \mathrm{~b}$ & $244.08 \pm 2.03 b$ \\
\hline 15 days & $77.85 \pm 0.39 a$ & $10.90 \pm 0.89 \mathrm{a}$ & $18.37 \pm 3.54 \mathrm{a}$ & $19.65 \pm 0.06 \mathrm{c}$ & $2.34 \pm 0.06 \mathrm{~d}$ & $52.24 \pm 4.54 \mathrm{a}$ & $254.04 \pm 1.58 \mathrm{a}$ \\
\hline \multicolumn{8}{|c|}{ C. patendra } \\
\hline 0 days & $70.45 \pm 0.52 \mathrm{a}$ & $25.67 \pm 1.12 \mathrm{a}$ & $31.50 \pm 1.50 \mathrm{a}$ & $15.20 \pm 0.05 a$ & $1.39 \pm 0.22 \mathrm{a}$ & $26.30 \pm 0.11 b$ & $142.61 \pm 7.74 a$ \\
\hline 5 days & $70.22 \pm 1.10 \mathrm{a}$ & $24.81 \pm 0.42 \mathrm{a}$ & $31.53 \pm 1.06 \mathrm{a}$ & $14.29 \pm 0.01 b$ & $1.15 \pm 1.03 \mathrm{~b}$ & $28.22 \pm 1.56 b$ & $145.24 \pm 4.96 \mathrm{a}$ \\
\hline 10 days & $69.97 \pm 0.17 \mathrm{a}$ & $23.67 \pm 0.05 \mathrm{a}$ & $31.66 \pm 1.06 \mathrm{a}$ & $13.46 \pm 0.08 \mathrm{c}$ & $0.97 \pm 1.03 \mathrm{c}$ & $30.24 \pm 1.14 \mathrm{a}$ & $148.90 \pm 3.51 \mathrm{a}$ \\
\hline 15 days & $66.62 \pm 3.01 \mathrm{a}$ & $23.18 \pm 0.04 \mathrm{a}$ & $31.78 \pm 1.62 \mathrm{a}$ & $12.48 \pm 0.11 \mathrm{~d}$ & $0.32 \pm 1.05 \mathrm{~d}$ & $33.14 \pm 1.52 \mathrm{a}$ & $151.44 \pm 5.48 \mathrm{a}$ \\
\hline
\end{tabular}

Data are represented as Means $\pm \mathrm{SD}(\mathrm{n}=3)$. Means in the column with no common letter differ significantly $(\mathrm{p}<0.05)$ for each leafy vegetable.

*: values given on dry matter basis.

Table 2. Mineral composition ( $\mathrm{mg} / 100 \mathrm{~g}$ dry matter) of refrigerated $\left(4^{\circ} \mathrm{C}\right)$ leafy vegetables consumed in Northern Côte d'Ivoire.

\begin{tabular}{|c|c|c|c|c|c|c|c|}
\hline & $\mathbf{C a}$ & Mg & $\mathbf{P}$ & $\mathbf{K}$ & $\mathbf{F e}$ & $\mathbf{N a}$ & Zn \\
\hline \multicolumn{8}{|c|}{ H.sabdariffa } \\
\hline 0 days & $402.21 \pm 0.55 \mathrm{a}$ & $295.93 \pm 0.41 \mathrm{a}$ & $407.59 \pm 0.00 \mathrm{a}$ & $816.19 \pm 1.12 \mathrm{a}$ & $102.08 \pm 0.14 \mathrm{a}$ & $23.46 \pm 0.03 a$ & $26.06 \pm 0.04 \mathrm{a}$ \\
\hline 5 days & $396.70 \pm 0.54 b$ & $252.80 \pm 0.32 b$ & $393.39 \pm 1.93 b$ & $726.15 \pm 4.45 b$ & $57.66 \pm 0.12 b$ & $23.13 \pm 0.16 \mathrm{a}$ & $24.96 \pm 0.74 b$ \\
\hline 10 days & $388.30 \pm 4.33 c$ & $233.06 \pm 5.10 \mathrm{c}$ & $386.30 \pm 5.05 \mathrm{c}$ & $647.52 \pm 0.95 c$ & $53.04 \pm 2.03 c$ & $22.93 \pm 2.88 \mathrm{a}$ & $23.27 \pm 0.03 b$ \\
\hline 15 days & $308.30 \pm 1.32 \mathrm{~d}$ & $229.52 \pm 6.02 \mathrm{c}$ & $341.82 \pm 4.81 \mathrm{~d}$ & $625.97 \pm 8.58 \mathrm{~d}$ & $49.88 \pm 2.32 \mathrm{~d}$ & $22.44 \pm 1.70 \mathrm{a}$ & $22.42 \pm 0.17 b$ \\
\hline \multicolumn{8}{|c|}{ A.hybridus } \\
\hline 5 days & $920.90 \pm 2.77 b$ & $486.69 \pm 2.77 b$ & $367.33 \pm 3.99 a$ & $1967.63 \pm 4.28 b$ & $73.58 \pm 2.88 b$ & $94.35 \pm 1.72 \mathrm{a}$ & $31.27 \pm 0.31 \mathrm{a}$ \\
\hline 10 days & $911.49 \pm 4.9 \mathrm{c}$ & $480.40 \pm 5.54 \mathrm{c}$ & $362.53 \pm 5.36 \mathrm{a}$ & $1954.53 \pm 7.75 \mathrm{c}$ & $69.33 \pm 3.47 \mathrm{~b}$ & $94.21 \pm 2.71 \mathrm{a}$ & $30.69 \pm 1.53 \mathrm{a}$ \\
\hline 15 days & $858.75 \pm 1.94 \mathrm{~d}$ & $451.19 \pm 7.57 \mathrm{~d}$ & $323.14 \pm 3.74 b$ & $1844.08 \pm 3.13 \mathrm{~d}$ & $49.29 \pm 8.51 \mathrm{c}$ & $93.66 \pm 1.28 \mathrm{a}$ & $27.07 \pm 0.7 \mathrm{~b}$ \\
\hline
\end{tabular}




\begin{tabular}{|c|c|c|c|c|c|c|c|}
\hline & Ca & $\mathrm{Mg}$ & $\mathbf{P}$ & $\mathbf{K}$ & $\mathrm{Fe}$ & $\mathbf{N a}$ & $\mathbf{Z n}$ \\
\hline \multicolumn{8}{|c|}{ A.digitata } \\
\hline 0 days & $496.26 \pm 2.20 \mathrm{a}$ & $264.36 \pm 1.17 \mathrm{a}$ & $761.63 \pm 0.00 \mathrm{a}$ & $1856.90 \pm 8.23 \mathrm{a}$ & $106.27 \pm 0.47 \mathrm{a}$ & $37.13 \pm 0.12 \mathrm{a}$ & $22.61 \pm 0.10 \mathrm{a}$ \\
\hline 5 days & $481.33 \pm 1.91 b$ & $228.19 \pm 1.49 b$ & $573.72 \pm 6.37 \mathrm{~b}$ & $1783.33 \pm 6.43 b$ & $73.35 \pm 1.77 b$ & $37.10 \pm 0.78 \mathrm{a}$ & $21.81 \pm 0.08 \mathrm{~b}$ \\
\hline 10 days & $474.82 \pm 3.83 c$ & $219.89 \pm 5.32 \mathrm{c}$ & $502.48 \pm 4.11 \mathrm{c}$ & $1777.52 \pm 1.12 \mathrm{c}$ & $72.34 \pm 0.47 b$ & $36.42 \pm 0.96 \mathrm{a}$ & $18.48 \pm 0.07 \mathrm{c}$ \\
\hline 15 days & $415.05 \pm 7.62 \mathrm{~d}$ & $213.64 \pm 3.34 d$ & $448.25 \pm 2.51 \mathrm{~d}$ & $1672.90 \pm 3.77 \mathrm{~d}$ & $71.50 \pm 1.12 b$ & $34.53 \pm 1.90 \mathrm{a}$ & $17.95 \pm 0.12 \mathrm{c}$ \\
\hline \multicolumn{8}{|c|}{ V.unguiculata } \\
\hline 0 days & $439.54 \pm 0.56 \mathrm{a}$ & $341.34 \pm 0.18 \mathrm{a}$ & $309.04 \pm 0.00 \mathrm{a}$ & $718.11 \pm 0.91 \mathrm{a}$ & $91.45 \pm 0.12 \mathrm{a}$ & $33.32 \pm 0.02 \mathrm{a}$ & $40.83 \pm 0.04 a$ \\
\hline 5 days & $430.81 \pm 6.26 b$ & $323.33 \pm 2.93 b$ & $306.30 \pm 1.94 a$ & $702.32 \pm 6.88 b$ & $88.03 \pm 0.88 \mathrm{~b}$ & $32.35 \pm 1.09 \mathrm{a}$ & $39.74 \pm 0.40 \mathrm{a}$ \\
\hline 10 days & $428.05 \pm 2.09 \mathrm{c}$ & $318.26 \pm 9.31 \mathrm{~b}$ & $301.58 \pm 8.09 \mathrm{a}$ & $653.67 \pm 3.69 \mathrm{c}$ & $85.09 \pm 3.10 \mathrm{~b}$ & $31.49 \pm 2.99 \mathrm{a}$ & $37.94 \pm 1.30 \mathrm{~b}$ \\
\hline 15 days & $423.54 \pm 4.01 \mathrm{c}$ & $310.35 \pm 3.19 c$ & $298.94 \pm 1.75 \mathrm{a}$ & $565.32 \pm 3.71 d$ & $82.70 \pm 4.51 \mathrm{~b}$ & $31.26 \pm 1.37 \mathrm{a}$ & $34.06 \pm 0.84 \mathrm{c}$ \\
\hline \multicolumn{8}{|c|}{ C.patendra } \\
\hline 0 days & $997.02 \pm 0.55 \mathrm{a}$ & $773.55 \pm 0.43 a$ & $570.85 \pm 2.11 \mathrm{a}$ & $1585.58 \pm 0.87 \mathrm{a}$ & $219.84 \pm 0.12 \mathrm{a}$ & $42.69 \pm 0.02 \mathrm{a}$ & $35.68 \pm 0.02 \mathrm{a}$ \\
\hline 5 days & $823.39 \pm 6.31 \mathrm{~b}$ & $661.01 \pm 1.76 b$ & $532.46 \pm 6.18 \mathrm{~b}$ & $1278.19 \pm 9.52 b$ & $168.09 \pm 0.59 b$ & $37.94 \pm 1.76 \mathrm{~b}$ & $34.67 \pm 0.78 \mathrm{a}$ \\
\hline 10 days & $819.21 \pm 1.91 \mathrm{~b}$ & $637.24 \pm 2.07 \mathrm{c}$ & $523.41 \pm 1.17 \mathrm{c}$ & $1211.88 \pm 2.11 \mathrm{c}$ & $160.53 \pm 0.41 \mathrm{c}$ & $36.78 \pm 0.70 b$ & $33.17 \pm 0.08 b$ \\
\hline 15 days & $744.50 \pm 1.65 \mathrm{c}$ & $610.14 \pm 5.34 \mathrm{~d}$ & $502.17 \pm 4.53 d$ & $1084.69 \pm 2.48 d$ & $152.36 \pm 3.82 \mathrm{~d}$ & $33.14 \pm 0.39 c$ & $27.10 \pm 0.02 c$ \\
\hline
\end{tabular}

Data are represented as Means $\pm \mathrm{SD}(\mathrm{n}=3)$. Means in the column with no common letter differ significantly $(\mathrm{p}<0.05)$ for each leafy vegetable.

Table 3. Anti-nutritional factors/mineral ratios of refrigerated $\left(4^{\circ} \mathrm{C}\right)$ leafy vegetables consumed in Northern Côte d' Ivoire.

\begin{tabular}{|c|c|c|c|}
\hline & Phytates/Ca & Phytates/Fe & Oxalates/Ca \\
\hline \multicolumn{4}{|c|}{ H.sabdariffa } \\
\hline 0 days & 0.21 & 0.85 & 3.26 \\
\hline 5 days & 0.19 & 1.34 & 3.28 \\
\hline 10 days & 0.16 & 1.20 & 2.83 \\
\hline 15 days & 0.16 & 1.00 & 3.33 \\
\hline \multicolumn{4}{|c|}{ A.hybridus } \\
\hline 0 days & 0.03 & 0.41 & 0.07 \\
\hline 5 days & 0.03 & 0.33 & 0.07 \\
\hline 10 days & 0.02 & 0.30 & 0.06 \\
\hline 15 days & 0.02 & 0.36 & 0.06 \\
\hline \multicolumn{4}{|c|}{ A.digitata } \\
\hline 0 days & 0.04 & 0.19 & 1.57 \\
\hline 5 days & 0.04 & 0.26 & 1.57 \\
\hline 10 days & 0.03 & 0.23 & 1.51 \\
\hline 15 days & 0.03 & 0.18 & 1.64 \\
\hline \multicolumn{4}{|c|}{ V.unguiculata } \\
\hline 0 days & 0.04 & 0.19 & 1.66 \\
\hline 5 days & 0.04 & 0.19 & 1.64 \\
\hline 10 days & 0.03 & 0.16 & 1.51 \\
\hline 15 days & 0.02 & 0.13 & 1.50 \\
\hline \multicolumn{4}{|c|}{ C.patendra } \\
\hline 0 days & 0.04 & 0.17 & 0.78 \\
\hline 5 days & 0.04 & 0.19 & 0.90 \\
\hline 10 days & 0.03 & 0.17 & 0.83 \\
\hline 15 days & 0.03 & 0.15 & 0.89 \\
\hline
\end{tabular}

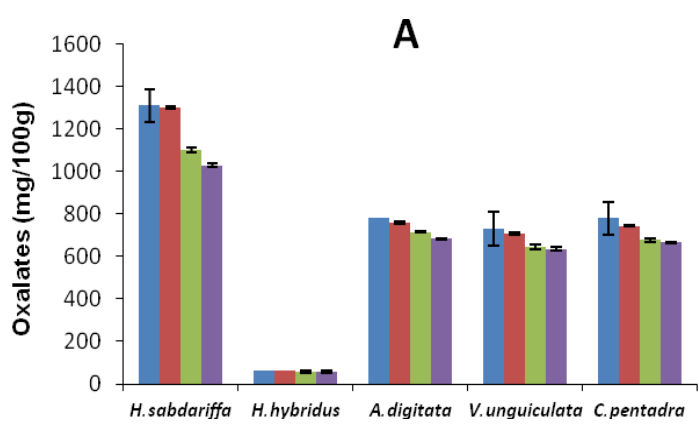

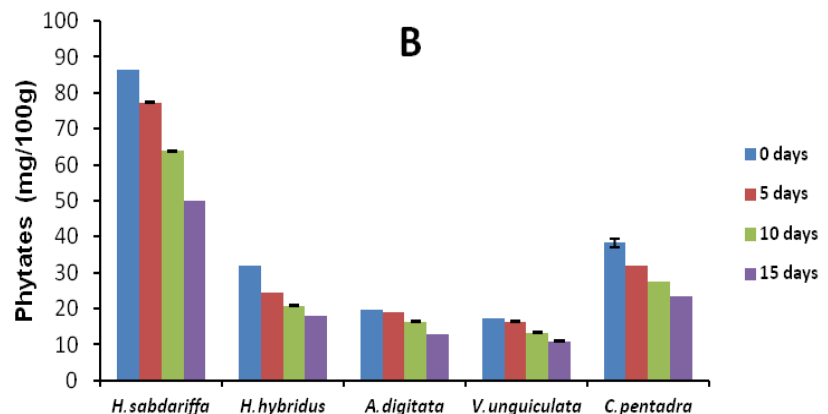

Figure 1. Oxalates $(A)$ and phytates $(B)$ contents of refrigerated $\left(4^{\circ} \mathrm{C}\right)$ leafy vegetables consumed in Northern Côte d'Ivoire.

\subsection{Antioxidant Properties}
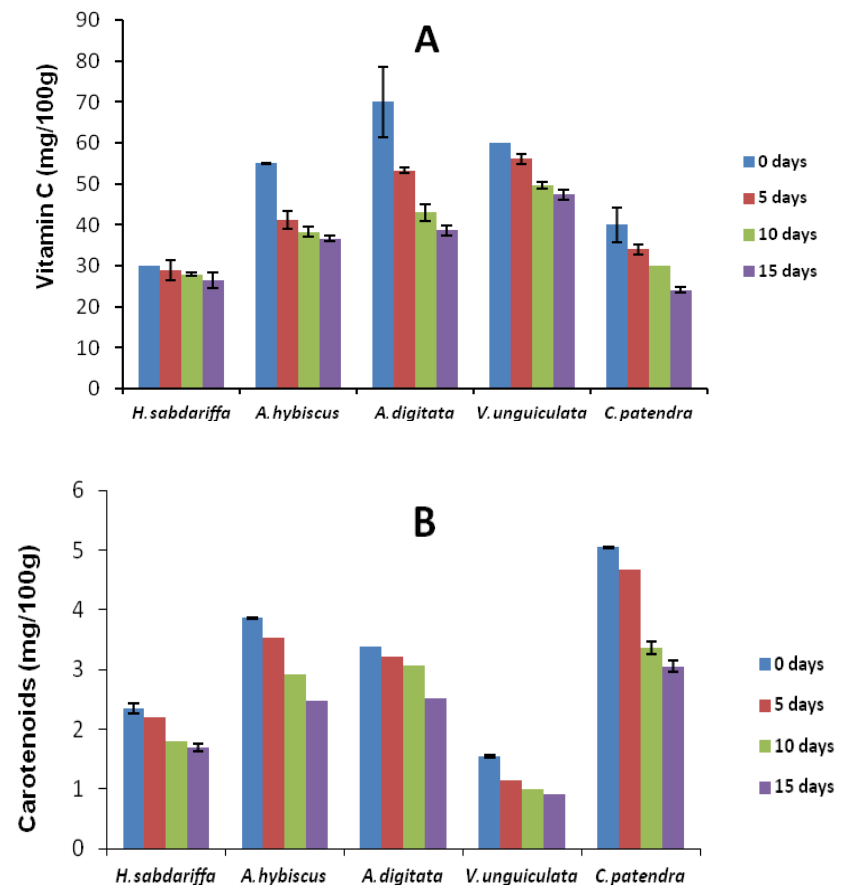

Figure 2. Vitamin $C(A)$ and carotenoids $(B)$ contents of refrigerated $\left(4^{\circ} \mathrm{C}\right)$ leafy vegetables consumed in Northern Cote d'Ivoire 

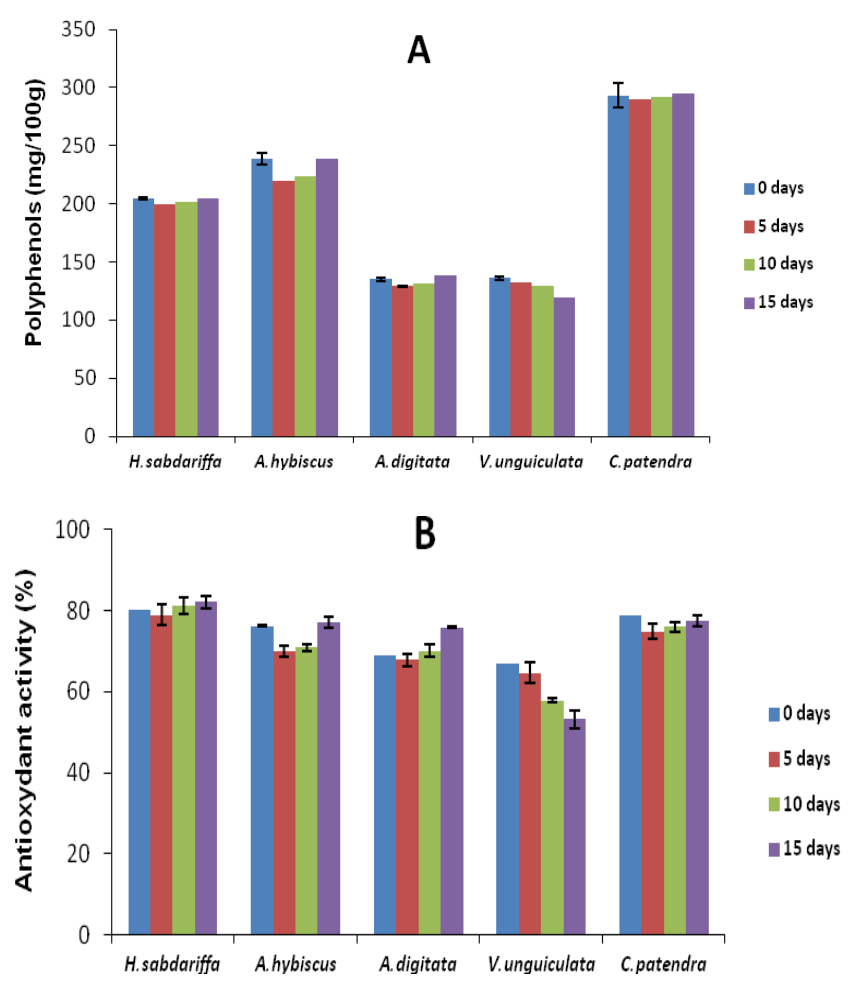

Figure 3. Polyphenols content (A) and antioxidant activity (B) of refrigerated $\left(4^{\circ} \mathrm{C}\right)$ leafy vegetables consumed in Northern Côte d'Ivoire

Refrigeration at $4^{\circ} \mathrm{C}$ resulted in a small decrease of carotenoids and vitamin $\mathrm{C}$ contents in the studied leafy vegetables (Figure 2). Carotenoids play an important potential role in human health by acting as biological antioxidants [36]. Carotenoids, losses at 5 days were estimated from 5.02 to $25.80 \%$. Loss of carotenoid contents during storage has been reported in numerous studies $[37,38]$. The decrease in the concentration of total carotenoids could be attributed to the degradation of pigments during refrigeration [39]. Vitamin $\mathrm{C}$ is vulnerable to enzymatic oxidation; therefore, it is sensitive and appropriate marker for monitoring quality change during, transportation, processing and storage $[40,41]$. Losses in vitamin $C$ ranged from 3.56 to $25 \%$ and 11.43 to $44.68 \%$ at 5 and 15 days, respectively of storage at $4^{\circ} \mathrm{C}$ (Figure 2). This result corroborates previous work [42] that reported only $20 \%$ retention of ascorbic acid in spinach stored under refrigerated temperature $\left(4^{\circ} \mathrm{C}\right)$ for 7 days. Also, the decrease of vitamin $\mathrm{C}$ content is in agreement with other studies [43, 44]. Vitamin C degradation is due to auto-oxidation and also enzymatic degradation. Indeed, vitamin $\mathrm{C}$ losses continue through post harvest handling, processing and storage of fruit and vegetables [45]. The effect of refrigeration on polyphenols content and antioxidant activity of the selected leafy vegetables is shown in figure 3 . Phenolic compounds also seem to be more affected by storage factors such as temperature, atmosphere and light, than either vitamin $\mathrm{C}$ or carotenoids [46]. At the beginning (0-day), the total phenolic content of the five fresh leafy vegetables ranged from 135.21 to $293.08 \mathrm{mg} / 100 \mathrm{~g}$. At the end of the storage (15 days) total phenolic content increased except for Vigna unguiculata. This increase in total phenols agrees with some reports $[47,44]$. During storage at $4^{\circ} \mathrm{C}$, the species showed variation of total phenolic; this trend was portrayed as an initial decrease followed by an increase in phenolic content. The decrease and increase in phenolic content during refrigeration may be due to degradation in phenolic compounds by enzyme action.

\section{Conclusion}

From the above investigation, it can be concluded that leafy vegetables consumed in Northern Côte d'Ivoire contain significant levels of nutrients that are essential for human health. However, refrigeration storage minimizes nutritive losses in the studied leafy vegetables. During refrigeration at $4^{\circ} \mathrm{C}$, small fluctuation in ash, fibres, proteins and fat were observed after 5, 10 and 15 days of storage. It was also observed a decrease of vitamin $\mathrm{C}$ and carotenoids and a cyclic variation in phenolic compounds. For best storage, the result of the present study recommends that leafy vegetables should be harvested fresh, washed free of soil and kept in perforated plastic bags within a few days (less than 5 days) at cleaned refrigerator since longer storage results in loss of freshness and flavor. In addition, each group of leafy vegetables must be separated (use one drawer for each group) in order to minimize the detrimental effects of ethylene produced during respiration phenomenon.

\section{References}

[1] Uzo, J.O. (1989). Tropical vegetable production. In: Food crops productions. Dotan publisher Ltd. Ibadan, 45-49.

[2] Uwaegbule, A. C. (1989). Vegetables: Nutrition and utilization. In: Food crops production. Dotan publishers Ltd. Ibadan, $39-44$.

[3] Nyaura, J.A, Sila, D.N, Owino, W.O. (2014). Post harvest stability of Vegetable Amaranthus (Amaranthus Dubius) combined low temperature and modified atmospheric packaging. Food Sci. Quality Management. Vol 30: ISSN 2224-6088.

[4] Akindahunsi, A.A. and Salawu, S.O. (2005). Phytochemical screening and nutrient and anti-nutrient composition of selected tropical green leafy vegetables. Afr. J. Biotechnol., 4:497-501.

[5] Orech, F.O., Akenga, T., Ochora J, Friis, H. and Aagaard-Hansen J. (2005). Potential toxicity of some traditional leafy vegetables consumed in Nyang'oma Division, Western Kenya. AJFAND. Available from: http://www.ajfand.net/index.htm.

[6] PROTA (2004). Ressources végétales de l'Afrique tropicale. Volume 2 : Légumes. Grubben G.J.H. et Denton O.A. (eds). Fondation PROTA / Backhuys Publishers / CTA, Wageningen. $737 \mathrm{p}$.

[7] Fondio, L., Kouamé, C., N'zi, J.C., Mahyao, A., Agbo, E. and Djidji A.H. (2007). Survey of indigenous leafy vegetable in the urban and peri-urban areas of Côte d'Ivoire. Acta Hort., 752: 287-289. 
[8] Soro, L.C., Atchibri, L.O., Kouadio, K.K. and Kouamé, C. (2012). Evaluation de la composition nutritionnelle des légumes-feuilles. J. Appl. Biosci., 51:3567-3573.

[9] Rickman, J.C, Barrett, D.M and Bruhn, C.M. (2007). Nutritional comparison of fresh, frozen and canned fruits and vegetables. Part 1. Vitamins $\mathrm{C}$ and $\mathrm{B}$ and phenolic compounds. J. Sci. Food Agric., 87:930-944.

[10] Prabhu, S and M Barrett, D. (2009). Effects of storage condition and domestic cooking on the quality and nutrient content of African leafy vegetables (Cassia tora and Corchorus tridens). J. Sci. Food Agric., 89:1709-1721

[11] Chinma, C.E., Igyor, M.A. (2007). Micro-nutriments and anti-nutritional content of select tropical vegetables grown in South-East, Nigeria. Nig. Food J., 25:111-115.

[12] AOAC (1990). Official methods of analysis. Association of Official Analytical Chemists Ed., Washington DC. 684 p.

[13] FAO (2002). Food energy-methods of analysis and conversion factors. FAO Ed, Rome. 97 p.

[14] Day, R.A. \& Underwood, A.L. (1986). Quantitive analysis 5th ed. Prentice Hall. 701p.

[15] Latta, M., Eskin, M. (1980). Simple method for phytate determination. J. Agric. Food Chem., 28: 1313-1315.

[16] CEAEQ (2013). Mineral determination. Argon plasma spectrometry method. MA 200 - Met 1.2, Rev 4. Quebec, 24 p.

[17] Pongracz, G., Weiser, H., Matzinger D. (1971). TocopherolsAntioxydant. Fat Sci. Technol., 97:90-104.

[18] Rodriguez-Amaya, D.B. (2001). A guide to carotenoids analysis in foods. ILSI Press, Washington DC. 64 p.

[19] Singleton, V.L., Orthofer, R. and Lamuela-Raventos, R.M. (1999). Analysis of total phenols and other oxydant substrates and antioxydants by means of Folin-ciocalteu reagent. Methods Enzymol., 299:152-178.

[20] Choi, C.W., Kim, S.C., Hwang S.S., Choi B.K., Ahn H.J., Lee M.Z., Park S.H. and Kim S.K. (2002). Antioxydant activity and free radical scavenging capacity between Korean medicinal plant and flavonoids by assay guided comparison. Plant Sci., 163:1161-1168

[21] FAO (1986). Food composition table for use in Africa.

[22] Herner, R.C. (1990). Factors affecting fiber content of asparagus. Great Lakes Veg Growers News 3:14-15.

[23] Jenkin, D.J., Jenkin, A.L., Wolever, T.M.S., Rao A.V., Thompson L.U. (1986). Fibre and starchy foods: function and implication in disease. Am. J .Gastroenterol., 81: 920-930.

[24] Ali, A. (2009). Proximate and mineral composition of the marchubeh (Asparagus officinalis). World Dairy Food Sci. 4: 142-149.

[25] Ejoh, A.R., Tchouanguep, M.F. and Fokou, E. (1996). Nutrient composition of the leaves and flowers of Colocasia esculenta and the fruits of Solanum melongena. Plant Food Hum. Nutr., 49: 107-112.

[26] Kris-Etherton, P.M., Hecker, K.D., Bonanome, A., Coval, S.M., Binkoski, A.E., Hilpert, K.F., Griel, A.E. \& Etherton, T.D. (2002). Bioactive compounds in foods: their role in the prevention of cardiovascular disease and cancer. PubMed, 9: 71-88.
[27] Sobowale, S.S., Olatidoye, O. P., Olorode, O.O., Akinlotan, J.V (2011). Nutritional potentials and chemical value of some tropical leafy vegetables consumed in south west Nigeria J. Sci. Multidisciplinary Res., 3: 55-65.

[28] FAO (2004). Human vitamin and mineral requirements. FAO Ed. 361p.

[29] Turan, M., Kordali, S., Zengin, H., Dursun, A. and Sezen Y. (2003). Macro and micro-mineral content of some wild edible leaves consumed in Eastern Anatolia. Plant Soil Sci., 53: 129-137.

[30] Chaturvedi, V.C., Shrivastava, R. and Upreti, R.K. (2004). Viral infections and trace elements: A complex trace element. Curr. Sci., 87:1536-1554.

[31] Narasinga Rao, B. S. (1997). Anemia in India: Prevalence, causes, consequences and control. Proceedings of Colloquium on Fortification of wheat flour with iron UNICEF and C.F.T.R.I Mysore, India, November 25.

[32] Trowbridge, F. and Martorell, M. (2002). Forging effective strategies to combat iron deficiency. J. Nutr., 85:875-880.

[33] Hassan, L.G.., Umar, K.J. and Umar, Z. (2007). Anti-nutritive factors in Tribulus terrestris (Linn) leaves and predicted calcium and zinc bioavailability. J. Trop. Biosci., 7:33-36..

[34] Umar, K.J., Hassan, L.G., Dangoggo, S.M., Inuwa, M. \& Amustapha, M.N. (2007). Nutritional content of Melochia corchorifolia Linn leaves. Int. J. Biol. Chem., 1: 250-255.

[35] Ekop, A.S. \& Eddy, N.O. (2005). Comparative studies of the level of toxicants in the seed of Indian almond (Terminalia catappa) and African walnut (Coula edulis). Chem. Class. J., 2: 74-76.

[36] Khalil, I. A and Saleemullah (2004). Book of Bio Analytical Chemistry 2nd Edt. National Book Foundation Islamabad: 26-29.

[37] Rajyalakshmi, P., K. Venkatalaxmi, K. Venkatalakshmamma, Y Jyothsna, K. Devi and V. Suneetha (2001). Total carotenoid and beta-carotene contents of forest green leafy vegetables consumed by tribals of south India. J. Food Sci., 56: 225-238.

[38] Mercela, C., B. Delia and R. Amaya (2003). Carotenoid composition of cooked green vegetables from restaurants. Food Chem., 83: 595-600.

[39] Gareth (1998). Losses of beta- carotene in stored amaranth vegetable in modified atmospheric package are usually due to oxidation mainly in the package.

[40] Wilhelmina, K. (2005). Effects of production and processing factors on major fruit and vegetable antioxidants. J. Food Sci., 70: 11-19.

[41] Degl'Innnocenti, E., Pardossi, A., Tognoni, F. \& Guidi, L. (2007). Physiological basis of sensitivity to enzymztic browning in 'Lettuce', 'escarole' and 'rocket salad' when stored as fresh-cut products. Food Chem., 104: 59-64

[42] Favell, D.J. (1998). A comparison of the vitamin C content of fresh and frozen vegetables. Food Chem., 62: 59-64.

[43] Howard L. A, Wong A. D, Perry A. K and Klein B. P. (1999). $\beta$-Carotene and ascorbic acid retention in fresh and processed vegetables. J Food Sci., 64:929-936. 
[44] Rivera, J. R. E., Stone, M. B., Stushnoff, C., Pilon-Smits, E. \& Kendall, P. A. (2006). Effects of Ascorbic acid applied by two hydrocooling methods on physical and chemical properties of green leaf lettuce stored at $5{ }^{\circ} \mathrm{C}$. J. Food Sci., 71:270-276.

[45] Moreira, M. D. R., Ponce, A. G., Valle, C. E. D. \& Roura, S. I. (2006). Ascorbic acid retention, microbial growth, and senory acceptability of lettuce leaves subjected to milk heat shocks. J. Food Sci., 71: 188-192.
[46] Souzan, S., Latif and Abd El-Aal, H. A. (2007). Minerals profile -shelf life extension and nutritive Value of fresh green leafy vegetables consumed in Egypt. Afr. Crop Sci. Conf. Proceeding, 8:1817-1826.

[47] Oboh G (2005). Effect of blanching on the antioxidant properties of some tropical green leafy vegetables. Lebensmittel-Wissenschaft Technol., 38: 513-517. 